\title{
The Relationship Between Fear of Missing Out (FoMO) Levels and Cyberloafing Behaviour of Teachers
}

\author{
Belis Feyza GÜLLÜ ${ }^{1} \&$ Hüseyin SERİN ${ }^{2}$ \\ ${ }^{1}$ Ministry of Education, Istanbul, Turkey \\ ${ }^{2}$ Department of Educational Sciences, Istanbul University-Cerrahpaşa, Istanbul, Turkey \\ Correspondence: Belis Feyza GÜLLÜ, Ministry of Education, Istanbul, Turkey. E-mail: \\ belis_4853@hotmail.com
}

Received: August 6, 2020 Accepted: September 7, 2020 Online Published: September 16, 2020

doi:10.5539/jel.v9n5p205 URL: https://doi.org/10.5539/jel.v9n5p205

\begin{abstract}
The purpose of this research was to investigate the relationship between teachers' fear of missing out (FoMO) levels and their cyberloafing behaviour and to reveal whether teachers' FoMO and their cyberloafing behaviour differ according to their gender. The sample of the research consisted of 702 secondary school teachers working in state schools within the borders of Istanbul in 2019-2020 education year. According to the research, it was identified that the level of teachers' FoMO levels and cyberloafing behaviours were moderate. It was detected that teachers' FoMO levels differed significantly according to gender. With this result, male teachers' FoMO levels were higher than female teachers' FoMO levels. Similarly, it was observed that there was a significant difference between teachers' cyberloafing behaviour and gender. According to this result, it was found that male teachers' mean score of cyberloafing behaviour was higher than female teachers' mean score of cyberloafing behaviour in all sub-scales. In addition, a positive significant relationship between teachers' FoMO and their cyberloafing behaviour was observed.
\end{abstract}

Keywords: cyberloafing, fear of missing out, teachers

\section{Introduction}

As a consequence of the internet, tools providing one-way communication such as newspapers and television, which defined as traditional media, have been replaced by new media which can be interacted independently of time and place. This situation has changed the habits of human life. With the help of the internet and the new media, which is a cornerstone of the information age, people can take a lot of transactions from banking to healthcare and from educational services to shopping. However, with the excessive use of internet and social network accounts, people have started to use social media uncontrollably and it has been seen that this kind of use caused some unwanted habits and even addictions (Gezgin et al., 2017).

With the result of the internet and social media, which are used as an educational tool, such concepts as FoMO or cyberloafing have been included in the literature. FoMO, which is thought that teachers have, can be defined as anxiety that more fun activities may take place outside in the current period of time and that the person is unaware and distant from this. It is possible that teachers may also have FoMO. Therefore, teachers may sometimes use the internet for personal purpose other than work-related purposes, and this situation may hinder their educational process. For this reason, it is thought that cyberloafing, which is thought to be related to teachers' FoMO, may also performed by teachers in educational organizations. At this point, it is thought that teachers who are one of the most important parts of the education, engage in cyberloafing activities in educational institutions and this situation may negatively affect the educational process.

It is thought to be a relationship between FoMO and cyberloafing activities. Tozkoparan and Kuzu (2019) found a significant relationship between FoMO and cyberloafing in their study, the sample of which consisted of 141 pre-service teachers. However, it can be seen that studies which investigate teachers' FoMO or cyberloafing behaviour in terms of various variables and observe the relationship between FoMO and cyberloafing behaviour from the point of teachers are limited. Despite well-prepared teaching plans and activities, cyberloafing may cause some problems in the education process. At this point, one of the factors which affect teachers' tendency to demonstrate cyberloafing behaviour can be their FoMO. Therefore, it can be said that investigating the 
relationship between teachers' FoMO levels and their cyberloafing behaviour is important.

It is seen that gender is one of the most associated concepts in the studies on FoMO and cyberloafing (Abel et al., 2016; Arslan et al., 2019; Blanchard \& Henle, 2008; Garret \& Danzinger, 2008; Przybylsky et al., 2013). Ahmad and Omar (2017) found a significant difference between cyberloafing and gender. In the study, it was found that male employees did more cyberloafing activities compared to female employees. In parallel with this study, Lim and Chen (2012) observed that men had a tendency to do cyberloafing activities more than women. Similar to these studies, Gezgin et al. (2017) found a significant difference between gender and FoMO. Consequnetly, it can be said that gender may be associated with FoMO and cyberloafing.

\subsection{Fear of Missing Out (FoMO)}

Fear of missing out (FoMO), with different definitions in the literature, is defined as a sort of social anxiety by Dossey (2013). The concept of FoMO has been associated with the perception of low self-confidence (Hosgor et al., 2017), social exclusion, anxiety, stress (Abel et al., 2016), communication difficulties in the real-life (Liftiah et al., 2016), the perception of scarcity that is used as a marketing strategy (Aydin, 2018; Lim, 2016), the desire to connect more economically in a cheaper way (Ellison et al., 2007), the desire to have information about each subject (Cinar, 2017). Along with these, it has been observed that FoMO affects people's mood and productivity (Abel et al., 2016; Adams et al., 2016; Baker et al., 2016; Caprara et al., 1985; Dossey, 2013; Gemmil \& Peterson, 2006; Pantic, 2012). Moreover, studies which are associated with the relationship between FoMO levels and personality traits, smartphone use and addiction, nomophobia level, subjective well-being or student motivation in terms of different variables are also available in the literature (Alt, 2015; Gezgin et al., 2017; Hato, 2013; Stead \& Bibby, 2017; Tanrikulu, 2018; Tras \& Oztemel, 2019). Gokler et al. (2016) and Alabi (2013) have demonstrated that with the increase in social media usage, individuals' addictive behaviour and FoMO levels can also increase according to their studies.

FoMO is a concept which may also affect teachers who are working in educational institutions. It is thought that with the developing technology, the fundamental reason behind this situation is the inclusion of the internet related educational tools into the educational organizations and the introduction of social media as an important communication and education tool. Similar to the other people working in other organizations, teachers who use the internet and social media to make the education process more qualified can also use the internet and social media for personal purpose. Teachers' frequent use of the internet, which meet the needs of teachers in many areas such as banking, healthcare, travel, socialization and personal development can cause FoMO in teachers. It is thought that teachers who frequently use the internet can have an impression that more fun activities are being done outside while they are performing educational duties. For this reason, teachers' FoMO can be defined as an anxiety of the possibility that more fun events can be happening in another place while they are performing education duties due to the posts they see on social networks and therefore teachers' desire to stay connected in social networks constantly.

\subsection{Cyberloafing}

The concept of cyberloafing was first created by Tony Cummins in 1995 with the combination of 'cyber' that means 'virtual' and 'loafing' that means 'slacking' and became widespread after Lim's (2002) study. In the international literature, the concept has been entitled as cyberloafing (Lim, 2002; Saleh et al., 2018), cyberslacking (Block, 2001; Vitak et al., 2011), and cyberdeviancy (Weatherbee, 2010).

There are a lot of definitions of cyberloafing. Lim (2002) defined cyberloafing as the use of internet access for the personal purpose at work by employees. According to Blanchard and Henle (2008), cyberloafing means personal internet and e-mail use during working hours. Cyberloafing is also defined as unapproved internet or computer use for entertainment by Askew (2009). In the lights of these definitions, it is possible to define cyberloafing as employees' use of informatics tools for purposes not related to their current duties (Unal \& Tekdemir, 2015). With the result of the internet which is the indispensable communication tool in educational organizations, there is a possibility that teachers can also do cyberloafing. In this study, teachers' cyberloafing behaviours are defined as 'activities that teachers do on the internet as an extra-curricular activity through their smartphones or school computer'.

It has been known that concepts of cyberloafing has been investigated with various concepts in the literature. Cyberloafing is associated with personality traits (Everton et al., 2005; Kaplan \& Ogut, 2012), organizational justice (Kelloway et al., 2010; Lim, 2002; Zoghbi, 2009), organizational trust (Orucu \& Ozudogru, 2018) and job satisfaction (Askew, 2012). Davis et al. (2002) state that problematic internet use may be related to the cognitive and behavioural characteristics of individuals, and that people who feel lonely tend to use the internet for social comfort. Such situations are thought to cause some negative consequences for organizations. Studies 
have shown that non-work-related internet use and cyberloafing behaviours cause cost loss and decrease employee productivity (Bock \& Ho, 2009; Liberman et al., 2011; Robinson \& Bennet, 1995). It is thought that these negative consequences related to cyberloafing are also valid for teachers, and this situation may affect educational activities negatively.

\section{Method}

\subsection{Research Goal}

In the study, it has been aimed to examine the relationship between teachers' FoMO levels and their cyberloafing behaviours and to reveal whether teachers' FoMO levels and their cyberloafing behaviour differ significantly according to gender.

\subsection{Sample}

The sample consists of 702 secondary school teachers working in state schools within the borders of Istanbul in 2019-2020 education year. Out of 702 teachers participating in the research, $372(53 \%)$ are women and 330 $(47 \%)$ are men. $351(50 \%)$ are married and $351(50 \%)$ are single. According to seniority of the teachers participated in the research, $79(11.3 \%)$ of the teachers are between the range of $1-5$ years, $156(22.2 \%)$ are in the range of 6-10 years, $171(24.4 \%)$ are in the range of $11-15$ years, $148(21.1 \%)$ are in the range of 16-20 years, $67(9.5 \%)$ is in the range of $21-25$ years and $81(11.5 \%)$ are between 26 and over.

\subsection{Data Collection}

To measure teachers' cyberloafing behaviour, the cyberloafing activities scale which was developed by Blanchard and Henle (2008), adapted to Turkish by Kalayci (2010) and updated by Yasar (2013) was used. The scale consists of 23 items and 4 sub-scales: personal, search, social and news sub-scales. According to the analysis carried out to determine the reliability level of the cyberloafing activities scale, Cronbach Alpha $(\alpha)$ coefficient is $\alpha=.94$ for the personal sub-scale, $\alpha=.93$ for search sub-scale, $\alpha=.92$ for social sub-scale and $\alpha$ $=.88$ for the news sub-scale. For this reason, it can be accepted that personal, search, social and news sub-scales of the cyberloafing activities scale are very reliable.

To determine the teachers' FoMO levels, fear of missing out (FoMO) scale which was developed by Przybylski et al. (2013) and adapted to Turkish by Gokler et al. (2016) was used. The scale consists of 10 items and one scale. According to reliability analysis which was performed to determine the reliability level of the FoMO scale, $\alpha=.95$ was found. According to this value, it is possible to say that FoMO scale is very reliable. Table 1 demonstrates the information about the item and scoring scale of the cyberloafing activities and FoMO scales.

Table 1. Information about item and scoring scale of the cyberloafing and FoMO scales

\begin{tabular}{lllll}
\hline Score Options & Score Range & Comment & Cyberloafing Options & FoMO Options \\
\hline 1 & $1.00-1.80$ & Very Low & Never & Strongly Disagree \\
2 & $1.18-2.60$ & Low & Seldom & Disagree \\
3 & $2.61-3.40$ & Moderate & Sometimes & Neutral \\
4 & $3.41-4.20$ & High & Usually & Agree \\
5 & $4.21-5.00$ & Very High & Always & Strongly Disagree \\
\hline
\end{tabular}

\subsection{Analyzing of Data}

Correlational survey method was used in the study, which aimed to examine the relationship between teachers' FoMO levels and their cyberloafing behaviours. In this context, quantitative research approach was used in the analysis of the data.

To analyse the data, IBM SPSS 23.0 program was used. Kolmogorov-Smirnov and Shapiro-Wilk normality tests, kurtosis-skewness and histogram graphics were used to determine whether the data set distributed normally. The analysis demonstrated that kurtosis and skewness values of all sub-scales of the scales were between -1.5 and +1.5 . Tabachnick and Fidell (2013) state that the value range of -1.5 and +1.5 and George and Mallery (2010) state that the range of -2 and +2 are acceptable values. For this reason, parametric analysis methods were used in this study.

Independent samples t-test was performed to examine whether teachers' FoMO levels differed significantly according to gender. Similarly, to find whether there was a significant difference between teachers' cyberloafing behaviour and gender, independent samples t-test was performed. Besides, Pearson correlation analysis was conducted to investigate whether there was a significant relationship between teachers' FoMO and their 
cyberloafing behaviour.

\section{Results}

The findings related to teachers' FoMO is shown in Table 2.

Table 2. Mean and standard deviation values of FoMO scale

\begin{tabular}{llll}
\hline \multirow{2}{*}{ FoMO } & $n$ & $\overline{\mathrm{X}}$ & $s d$ \\
\cline { 2 - 4 } & 702 & 2.705 & 1.159 \\
\hline
\end{tabular}

When the mean score of FoMO in Table 2 is analysed, it can be said that teachers' FoMO level is moderate $(\overline{\mathrm{X}}=$ $2.705, s d=1.159)$.

To determine whether teachers' FoMO differs significantly according to gender, independent samples t-test was conducted. Independent samples t-test results related to teachers' FoMO according to gender are given in Table 3.

Table 3. Independent samples t-test results related to teachers' FOMO in terms of gender

\begin{tabular}{llllllll}
\hline Gender & $n$ & $\overline{\mathrm{X}}$ & $s d$ & $\mathrm{df}$ & $\mathrm{t}$ & $\mathrm{p}$ & Cohen $\mathrm{d}$ \\
\hline Female & 372 & 2.37 & 1.05 & 670 & -8.31 & $* 00$ & .063 \\
Male & 330 & 3.07 & 1.15 & & & & \\
\hline
\end{tabular}

Note. ${ }^{*} \mathrm{p}<.05$.

According to Table 3, teachers' FoMO levels differ according to gender $\left(\mathrm{t}_{(670)}=-8.31, \mathrm{p}<.05\right)$. The mean score of FoMO levels of male teachers $(\overline{\mathrm{X}}=3.07)$ is higher than the mean score of FoMO levels of female teachers $(\overline{\mathrm{X}}$ $=2.37$ ). Cohen (1988) states that if the effect size is .02, the effect size is low if .05 , the effect size is medium and if it is .08 , the effect size is high. According to this, the effect size (Cohen $\mathrm{d}=.063$ ) demonstrates that the effect size of this difference is high.

Mean total score of teachers' cyberloafing behaviour and mean scores of sub-scales are shown in Table 4 . According to this result, mean total score of cyberloafing is $\bar{X}=2.621$. While 'social' sub-scale is the highest sub-scale with $\bar{X}=2.898$, 'personal' sub-scale is the lowest sub-scale with $\bar{X}=2.394$. Besides the mean score of 'search' sub-scale is $\overline{\mathrm{X}}=2.782$. Also, the mean score of 'news' sub-scale is $\overline{\mathrm{X}}=2.769$.

Table 4. Mean score and standard deviation values related to cyberloafing activities scale

\begin{tabular}{|c|c|c|c|}
\hline & $\mathrm{n}$ & $\overline{\mathrm{X}}$ & $s d$ \\
\hline Personal & 702 & 2.394 & 1.117 \\
\hline Search & 702 & 2.782 & 1.163 \\
\hline Social & 702 & 2.898 & 1.254 \\
\hline News & 702 & 2.769 & 1.126 \\
\hline Cyberloafing (Total) & 702 & 2.621 & 1.133 \\
\hline
\end{tabular}

Note. ${ }^{*} \mathrm{p}<.05$.

Independent samples t-test was performed to observe whether mean scores of teachers' cyberloafing differ significantly according to gender. Independent samples t-test is demonstrated in Table 5. 
Table 5. Independent samples t-test related to cyberloafing behaviour in terms of gender

\begin{tabular}{lllllllll}
\hline \multirow{2}{*}{ Individual } & Gender & $\mathrm{n}$ & $\overline{\mathrm{X}}$ & sd & $\mathrm{df}$ & $\mathrm{t}$ & $\mathrm{P}$ & Cohen d \\
\cline { 2 - 9 } Search & Female & 372 & 2.07 & 1.00 & 661 & -8.28 & $.00^{*}$ & .062 \\
& Male & 330 & 2.75 & 1.13 & & & & \\
\multirow{5}{*}{ Social } & Female & 372 & 2.41 & 1.05 & 700 & -9.48 & $.00^{*}$ & .071 \\
& Male & 330 & 3.19 & 1.13 & & & & \\
News & Female & 372 & 2.53 & 1.15 & 700 & -8.44 & $.00^{*}$ & .063 \\
& Male & 330 & 3.30 & 1.23 & & & & .050 \\
Cyberloafing & Female & 372 & 2.51 & 1.13 & 698 & -6.68 & $.00^{*}$ & .006 \\
(Total) & Male & 330 & 3.06 & 1.04 & & & & .064 \\
\hline
\end{tabular}

Note. ${ }^{*} \mathrm{p}_{<.05}$.

When Table 5 is examined, teachers' cyberloafing shows a significant difference in terms of gender $\left(\mathrm{t}_{(700)}={ }_{-8.62}\right.$, $\mathrm{p}<.05)$. According to this result, the mean score of male teachers' cyberloafing $(\bar{X}=2.99)$ is higher than the mean score of female teachers' cyberloafing $(\bar{X}=2.29)$. The effect size of cyberloafing (Cohen $d=.064)$ demonstrates that the effect size of this difference is high. 'Personal' sub-scale $\left(\mathrm{t}_{(661)}=-8.28, \mathrm{p}<.05\right)$, 'search' sub-scale $\left.\left(\mathrm{t}_{(700)}\right)={ }_{-9.48}, \mathrm{p}<.05\right)$, 'social' sub-scale $\left.\left(\mathrm{t}_{(700)}\right)=-8.44, \mathrm{p}<.05\right)$ and 'news' sub-scale $\left(\mathrm{t}_{(698)}=-6.68, \mathrm{p}\right.$ $<.05)$ show significant difference in terms of gender. The effect sizes of 'personal' sub-scale (Cohen $\mathrm{d}=.062)$, 'search' sub-scale (Cohen $\mathrm{d}=.071)$, 'social' sub-scale (Cohen $\mathrm{d}=.063$ ) and 'news' sub-scale (Cohen $\mathrm{d}=.050)$ show that the effect size of the differences of all sub-scales is high. It has been determined that for male teachers, the mean score of 'personal' sub-scale is $\overline{\mathrm{X}}=2.75$, 'search' sub-scale is $\overline{\mathrm{X}}=3.19$, 'social' sub-scale is $\overline{\mathrm{X}}=3.30$ and 'news' sub-scale is $\bar{X}=3.06$. For female teachers, the mean score of 'personal' sub-scale is $\bar{X}=2.07$, 'search' sub-scale is $\overline{\mathrm{X}}=2.41$, 'social' sub-scale is $\overline{\mathrm{X}}=2.53$ and 'news' sub-scale is $\overline{\mathrm{X}}=2.51$. According to these results, it can be seen that the mean score of male teachers is higher than the mean score of female teachers for all sub-scales of cyberloafing activities scale.

To analyse whether there is a significant relationship between teachers' FoMO levels and their cyberloafing behaviour, Pearson correlation analysis was conducted. Table 6 demonstrates the results of Pearson correlation analysis that was conducted.

Table 6. The results of Pearson correlation analysis related to FoMO and sub-scales of cyberloafing activities scale

\begin{tabular}{|c|c|c|c|c|c|c|c|c|}
\hline & $\mathrm{n}$ & $s d$ & FoMO & Personal & Search & Social & News & Cyberloafing \\
\hline FoMO & 702 & 1.159 & 1 & & & & & \\
\hline Personal & 702 & 1.117 & $.715 * *$ & 1 & & & & \\
\hline Search & 702 & 1.163 & $.761 * *$ & $.784 * *$ & 1 & & & \\
\hline Social & 702 & 1.259 & $.776^{* *}$ & $.732 * *$ & $.798 * *$ & 1 & & \\
\hline News & 702 & 1.126 & $.601 * *$ & $.683 * *$ & $.665 * *$ & $.666 * *$ & 1 & \\
\hline Cyberloafing & 702 & 1.133 & $.804 * *$ & $.887^{* *}$ & $.894 * *$ & $.862 * *$ & $.764 * *$ & 1 \\
\hline
\end{tabular}

Note. ${ }^{* * \mathrm{p}}<.01$.

When Table 6 is examined, there is a positive significant relationship between teachers' FoMO and their cyberloafing behaviour $(\mathrm{r}=.804, \mathrm{p}<.01)$. This relationship level is high. Besides, there is a significant relationship between teachers' FoMO levels and all sub-scales of cyberloafing activities scale. According to this, there is a high level of a significant relationship between teachers' FoMO levels and 'personal' sub-scale of cyberloafing $(\mathrm{r}=.715, \mathrm{p}<.01)$. Similarly, there is a high level of a significant relationship between teachers' FoMO and 'search' sub-scale of cyberloafing $(r=.761, \mathrm{p}<.01)$. It can also be seen that there is a high level of a significant relationship between teachers' FoMO levels and 'social' sub-scale $(\mathrm{r}=.776, \mathrm{p}<.01)$. Finally, there is a moderate level of a significant relationship between teachers' FoMO levels and 'news' sub-scale of cyberloafing activities scale $(\mathrm{r}=.601, \mathrm{p}<.01)$.

The square of the correlation coefficient $\left(\mathrm{r}^{2}\right)$ is called the determination coefficient and this shows how much change in one variable can be explained by another variable (Can, 2017). The results of Pearson correlation analysis showed that the determination coefficient was found as $\left[(.804)^{2}=.64\right]$. Accordingly, the change in teachers' FoMO level can explain $64 \%$ of their cyberloafing behaviour. In other words, the change in teachers' 
cyberloafing behaviour can explain $64 \%$ of their FoMO levels.

\section{Discussion}

In this study, it has been investigated the relationship between teachers' FoMO levels and their cyberloafing behaviour and has been revealed whether there is a significant difference between teachers' FoMO levels and gender. Besides, it has been examined whether teachers' cyberloafing behaviour shows significant difference in terms of gender. In this direction, 702 secondary teachers working in public schools in the borders of Istanbul in 2019-2020 education year formed the sample of the study.

According to the results gained from the study teachers' FoMO levels are in the moderate level. Moreover, teachers' FoMO levels show a significant difference in terms of gender. It has been observed that male teachers' FoMO levels are higher than female teachers' FoMO levels. This situation may derive from the fact that male teachers' desire to stay connected is higher than female teachers. Correlatively, Arslan et al. (2019), Gezgin et al. (2017) and Przybylsky et al.'s (2013) results support the study. On the other side, Abel at al. (2016) and Hizarci (2018) found no significant difference between FoMO and gender in their studies. Analysed in the literature, there is no consensus associated with FoMO and gender. The lack of consensus may stem from the difference in various variables such as occupation, age, current geographical area, marital status, psychological factors and organizational factors.

In the study, the mean scores of teachers' cyberloafing behaviour and 'personal', 'search', 'social', 'news' sub-scales are in moderate level. Based on the means of all sub-scales, it is observed that teachers show cyberloafing behaviour which is in the 'news' sub-scale at most. With these results, it possible to say that teachers' cyberloafing behaviour is at a moderate level.

It has been found that the mean scores of cyberloafing and all sub-scales of cyberloafing show significant difference according to gender. This means that the mean scores of male teachers' cyberloafing behaviour are higher than female teachers' cyberloafing behaviour in all sub-scales. It can be said that male teachers' desire to be up to date is higher than female teachers. This result is consistent with Ahmad and Omar (2017), Blanchard and Henle (2008), Garret and Danzinger (2008), Lim and Chen's (2012) study. However, no significant difference was found between cyberloafing and gender in Anandarajan and Simmers (2004), Bagriacik-Yilmaz (2017), Kilic and Kocabas (2017), Lavoie and Pychyl's (2001) studies.

The final result of the study demonstrates that there is a significant positive relationship between teachers' FoMO levels and their cyberloafing behaviour. Moreover, the result of the study demonstrates a significant positive relationship between teachers' FoMO levels and 'personal', 'search', 'social', 'news' sub-scales of cyberloafing. It may stem from the increase in the desire of teachers to stay connected since they think that other people outside are doing more fun activities at that time, and this thought may cause more FoMO in teachers. The determination coefficient which has been gained from Pearson correlation analysis has been determined as $\left[(.804)^{2}=.64\right]$. With this result, the change in teachers' FoMO levels can explain $64 \%$ of their cyberloafing behaviour. In other words, teachers' cyberloafing behaviour can explain $64 \%$ of their FoMO levels. Similar to the study, a significant relationship between FoMO and cyberloafing was detected in Ozcan's (2019) study. In Tozkoparan and Kuzu's (2019) study, no significant relationship between FoMO and 'personal', 'search' and 'news' sub-scales of cyberloafing is found; however, there is a significant relationship between FoMO and 'social' sub-scale of cyberloafing.

This study is limited to the secondary school teachers working in public schools within the borders of Istanbul in 2019-2020 education year. Besides, the demographic variable of the study is limited to gender. The findings of other studies which investigate the relationship between teachers' FoMO levels and their cyberloafing activities can be expanded by adding teachers who work in different educational institutions or in different regions. At this point, to have more information, qualitative research can be conducted by getting students' opinions towards their teachers FoMO levels or their cyberloafing activities.

\section{Acknowledgments}

This study was performed from an M. Ed thesis entitled 'The Investigation into the Relationship Between Fear of Missing Out Levels and Cyberloafing Behaviours of Teachers' written by Belis Feyza GÜLLÜ under the supervision of Asst. Prof. Hüseyin SERIN the Department of Educational Sciences, Istanbul University-Cerrahpaşa, Istanbul, Turkey.

\section{References}

Abel, J. P., Buff, C. L., \& Burr, S. A. (2016). Social media and the fear of missing out: Scale development and assessment. Journal of Bussiness \& Economics Research (JBER), 14(1), 33-44. 
https://doi.org/10.19030/jber.v14i1.9554

Adams, S. K., Williford, D. N., Vaccaro, A., Kisler, T. S., Francis, A., \& Newman, B. (2016). The young and the restless: Socializing trumps sleep, fear of missing out, and technological distractions in fist year college students. International Journal of Adolescence and Youth, 22(3), 337-348. https://doi.org/10.1080/02673843.2016.1181557

Ahmad, A., \& Omar, Z. (2017). Understanding who cyberloafs from the self-control perspective: A study in the public service sector. International Journal of Advanced and Applied Sciences, 4(8), 123-128. https://doi.org/10.21833/ijaas.2017.08.017

Alabi, O. F. (2013). A survey of facebook level among selected nigerian university undergraduates. New Media and Mass Communication, 10, 70-80.

Alt, D. (2015). College students' academic motivation, media engagement and fear of missing out. Computers in Human Behavior, 49, 111-119. https://doi.org/10.1016/j.chb.2015.02.057

Anandarajan, M., \& Simmers, C. A. (2004). Personal web usage in the workplace: A guide to effective human resources management. IGI Global. https://doi.org/10.4018/978-1-59140-148-3

Arslan, H., Tozkoparan, S. B., \& Kurt, A. A. (2019). Ogretmenlerde mobil telefon yoksunlugu korkusunun ve gelismeleri kacirma korkusunun incelenmesi. Erzincan University Journal of Education Faculty, 21(3), 237-256. https://doi.org/10.17556/erziefd.512074

Askew, K. L. (2009). Testing the plausibility of a series of causal minor cyberloafing models. Master's thesis, University of South Florida. Retrieved https://scholarcommons.usf.edu/cgi/viewcontent.cgi?article $=4729 \&$ context=etd

Askew, K. L. (2012). The relationship between cyberloafing and task performance and an examination of the theory of planned behavior as a model of cyberloafing. Doctoral Dissertation, University of South Florida. Retrieved from https://scholarcommons.usf.edu/cgi/viewcontent.cgi?referer=\&httpsredir=1\&article=5153\&context=etd

Aydin, H. (2018). Sosyal medyadaki gelismeleri kacirma korkusunun (FoMO) icgudusel alimlara etkisinin oz belirleme kurami ile aciklanmasi. International Journal of Economics and Administrative Studies, 17, 415-426. https://doi.org/10.18092/ulikidince.439179

Bagriacik-Yilmaz, A. (2017). Lisansustu ogrencilerinin siber aylaklik duzeylerinin cesitli degiskenler acisindan incelenmesi: Karma bir calisma. Journal of Kirsehir Education Faculty, 18(2), 113-134.

Baker, Z. G., Krieger, H., \& LeRoy, A. (2016). Fear of missing out: Relationships with depression, mindfulness, and physical symptoms. Translational Issues in Psychological Science, 2(3), 275. https://doi.org/10.1037/tps0000075

Blanchard, A. L., \& Henle, C. A. (2008). Correlates of different forms of cyberloafing: The role of norms and external locus of control. Computers in Human Behavior, 24(3), 1067-1084. https://doi.org/10.1016/j.chb.2007.03.008

Block, W. (2001). Cyberslacking, business ethics and managerial economics. Journal of Business Ethics, 33(3), 225-231. https://doi.org/10.1023/A:1012002902693

Bock, G. W., \& Ho, S. L. (2009). Non-work related computing (NWRC). Communications of the ACM, 52(4), 124-128. https://doi.org/10.1145/1498765.1498799

Can, A. (2017). SPSS ile bilimsel arastirma surecinde nicel veri analizi. Pegem Akademi.

Caprara, G. V., Cinanni, V., D’imperio, G., Passerini, S., Renzi, P., \& Travaglia, G. (1985). Indicators of impulsive aggression: Present status of research on irritability and emotional susceptibility scales. Personal and Individual Differences, 6(6), 665-674. https://doi.org/10.1016/0191-8869(85)90077-7

Cinar, C. Y. (2017). The level of fear of missing out and related factors among university students. Master's thesis, Istanbul Gelisim University. https://tez.yok.gov.tr/UlusalTezMerkezi/tezSorguSonucYeni.jsp

Cohen, J. (1988). Statistical power analysis for the behavioral sciences (2nd ed.). Lawrence Erlbaum Associates.

Davis, R. A., Flett, G. L., \& Besser, A. (2002). Validation of a new scale for measuring problematic internet use: implications for pre-employment screening. CyberPsychology \& Behavior, 5(4), 331-345. https://doi.org/10.1089/109493102760275581 
Dossey, L. (2013). FOMO, Digital dementia, and our dangerous experiment. Explore: The Journal of Science and Healing, 10(2), 69-73. https://doi.org/10.1016/j.explore.2013.12.008

Ellison, N. B. C. S., \& Lampe, C. (2007). The benefits of facebook 'friends' social capital and college students' use of online social network sites. Journal of Computer-Mediated Communication, 12(4), 1143-1168. https://doi.org/10.1111/j.1083-6101.2007.00367.x

Everton, W. J., Mastrangelo, P. M., \& Jolton, J. A. (2005). Personality correlates of employees' personal use of work computers. CyberPsychology \& Behavior, 8(2), 143-153. https://doi.org/10.1089/cpb.2005.8.143

Garret, R. K., \& Danziger, J. N. (2008). On cyberslacking: Workplace status and personal internet use at work. CyberPsychology \& Bahevior, 11(3), 287-292. https://doi.org/10.1089/cpb.2007.0146

Gemmil, E., \& Peterson, M. (2006). Technology use among college students' implications for student affairs professionals. NASPA Journal, 43(2), 280-300. https://doi.org/10.2202/1949-6605.1640

George, D., \& Mallery, M. (2010). SPSS for windows step by step: a simple guide and reference, 17.0 update (10th ed.). Pearson.

Gezgin, D. M., Hamutoglu, N. B., Gemikonakli, O., \& Raman, I. (2017). Social networks users: Fear of missing out in preservice teachers. Journal of Education and Practice, 8(17), 156-168. Retrieved from https://files.eric.ed.gov/fulltext/ED579882.pdf

Gokler, M. E., Aydin, R., Unal, E., \& Metintas, S. (2016). Sosyal ortamlarda gelismeleri kacirma korkusu olceginin turkce surumunun gecerlilik ve guvenilirliginin degerlendirilmesi. Anatolian Journal of Psychiatry, 17(1), 52-59. https://doi.org/10.5455/JNBS.1494334674

Hato, B. (2013). (Compulsive) mobile phone checking behavior out of a fear of missing out: development, psychometric properties and test-retest reliability of a c-fomo-scale. Master's thesis, Tilburg University. Retrieved from http://arno.uvt.nl/show.cgi?fid=130541

Hizarci, O. (2018). An examination of the relationship between problematic cell phone use, fear of missing out (FoMO), life satisfaction and attachment styles in terms of demographic variables (Uskudar university-an example of graduate students in uskudar university). Master's thesis, Uskudar University. Retrieved from https://tez.yok.gov.tr/UlusalTezMerkezi/tezSorguSonucYeni.jsp

Hosgor, H., Koc-Tutuncu, S., Gunduz-Hosgor, D., \& Tandogan, O. (2017). Universite ogrencileri arasinda sosyal medyadaki gelismeleri kacirma korkusu yayginliginin farkli degiskenler acisindan incelenmesi. International Journal of Academic Value Studies (Javstudies), 3(17), 231-223. https://doi.org/10.23929/javs.668

Kalayci, E. (2010). Investigation of relationship between cyberloafing and self-regulated learning strageties among undergraduate students. Master's thesis, Hacettepe University. Retrieved from https://tez.yok.gov.tr/UlusalTezMerkezi/tezSorguSonucYeni.jsp

Kaplan, M., \& Ogut, A. (2012). Algilanan orgutsel adalet ile sanal kaytarma arasindaki iliskinin analizi: Hastane calisanlari ornegi. Dokuz Eylul Universitesi Isletme Fakultesi Dergisi, 13(1), 1-13. Retrieved from http://acikerisim.deu.edu.tr:8080/xmlui/bitstream/handle/20.500.12397/2406/1.pdf?sequence=1\&isAllowed $=\mathrm{y}$

Kelloway, E. K., Francis, L., Prosser, M., \& Cameron, J. E. (2010). Counterproductive work behavior as protest. Human Resource Management Review, 20(1), 18-25. https://doi.org/10.1016/j.hrmr.2009.03.014

Kilic, G. N., \& Kocabas, I. (2017). Ogretmenlerin okulda internet ve teknoloji kullanimina iliskin sanal kaytarma davranislarinin incelenmesi. The Journal of Kesit Academy, 10, 715-731. https://doi.org/10.18020/kesit.1236

Lavoie, J. A., \& Pychyl, T. A. (2001). Cyberslacking and the procrastination superhighway: A web-based survey of online procrastination, attitudes, and emotion. Social Science Computer Review, 19(4), 431-444. https://doi.org/10.1177/089443930101900403

Liberman, B., Seidman, G., Mckenna, K. Y., \& Buffardi, L. E. (2011). Employee job attitudes and organizational characteristics as predictors of cyberloafing. Computers in Human Behavior, 27(6), 2192-2199. https://doi.org/10.1016/j.chb.2011.06.015

Liftiah, D. L. F., \& Tresnawati, F. R. (2016). Personality traits prediction of fear of missing out in college students. The International Journal of Indian Psychology, 3(4), 128-136. Retrieved from https://ijip.in/articles/personality-traits-prediction-of-fear-of-missing-out-in-college-students/ 
Lim, V. K. (2002). The IT way of loafing on the job: Cyberloafing, neutralizing and organizational justice. Journal of Organizational Behavior, 23(5), 675-694. https://doi.org/10.1002/job.161

Lim, V. K., \& Chen, D. J. (2012). Cyberloafing at the workplace: Gain or drain on work? Behavior \& Information Technology, 31(4), 343-353. https://doi.org/10.1080/01449290903353054

Lim, Z. C. W. (2016). Tendency towards the fear of missing out. Doctoral dissertation, Curtin University. Retrieved from https://espace.curtin.edu.au/bitstream/handle/20.500.11937/54111/Lim\%20Zi\%20Cheng\%202017\%205\%2 0years.pdf? sequence $=1 \&$ isAllowed $=\mathrm{y}$

Orucu, E., \& Ozudogru, M. (2018). A research on identifying the relation between organizational trust and cyberloafing behaviours. Adnan Menderes University. Journal of Institute of Social Sciences, 5(3), 66-80. https://doi.org/10.30803/adusobed.407273

Ozcan, H. M. (2019). The role of fear of missing out (FoMO) in the relationship between personality traits and cyberloafing. Doctoral dissertation, Eskisehir Osmangazi University. Retrieved from https://tez.yok.gov.tr/UlusalTezMerkezi/tezSorguSonucYeni.jsp

Pantic, I., Damjanovic, A., Todorovic, J. T., BojovicJovic, D., Ristic, S., \& Pantic, S. (2012). Association between online social networking and depression in high school students: Behavioral physiology viewpoint. Psychiatria Danubina, 24(1), 90-93.

Przybylski, A. K., Murayama, K., \& DeHaan, C. R. (2013). Motivational, emotional, and behavioral correlates of fear of missing out. Computers in Human Behavior, 29(4), 1841-1848. https://doi.org/10.1016/j.chb.2013.02.014

Robinson, S. L., \& Bennet, R. J. (1995). A typology of deviant workplace behaviors: A multidimensional scaling study. Academy of Management Journal, 38(2), 555-572. https://doi.org/10.2307/256693

Saleh, M., Daqqa, I., AbdulRahim, M. B., \& Sakallah, N. (2018). The effect of cyberloafing on employee productivity. International Journal of Advanced and Applied Sciences, 5(4), 87-92. https://doi.org/10.21833/ijaas.2018.04.011

Stead, H., \& Bibby, P. A. (2017). Personality, fear of missing out and problematic internet use and their relationship to subjective well-being. Computers in Human Behavior, 76, 534-540. https://doi.org/10.1016/j.chb.2017.08.016

Tabachnick, B. G., \& Fidell, L. S. (2013). Using multivariate statistics (6th ed.). Pearson.

Tanrikulu, G. (2018). "I need to be updated": Fear of missing out and its antecedents as predictors of adolescents' and emerging adults' aspects of social media addiction. Master's thesis, Ted University. Retrieved from https://tez.yok.gov.tr/UlusalTezMerkezi/tezSorguSonucYeni.jsp

Tozkoparan, S. B., \& Kuzu, A. (2019). The relationship between fear of missing out (FoMO) levels and cyberloafing behaviors of teacher candidates. Anadolu Journal of Educational Sciences International, 9(1), 87-110. https://doi.org/10.18039/ajesi.520825

Tras, Z., \& Oztemel, K. (2019). Facebook yogunlugu, gelismeleri kacirma korkusu ve akıllı telefon bagımlılıgı arasindaki iliskinin incelenmesi. Addicta: The Turkish Journal of Addictions, 6(1), 91-113. https://doi.org/10.15805/addicta.2019.6.1.0063

Unal, O. F., \& Tekdemir, S. (2015). Sanal kaytarma: Bir kamu kurumunda ampirik bir arastirma. Suleyman Demirel University. The Journal of Faculty of Economics and Administrative Sciences, 20(2), 95-118. Retrieved from https://dergipark.org.tr/tr/download/article-file/194136

Vitak, J., Crouse, J., \& LaRose, R. (2011). Personal internet use at work: Understanding cyberslacking. Computers in Human Behavior, 27(5), 1751-1759. https://doi.org/10.1016/j.chb.2011.03.002

Weatherbee, T. G. (2010). Counterproductive use of technology at work: Information \& communications technologies and cyberdeviancy. Human Resource Management Review, 20(1), 35-44. https://doi.org/10.1016/j.hrmr.2009.03.012

Yasar, S. (2013). The effects of students' locus of control and attitudes towards computer laboratory on their cyberloafing behaviour. Master's thesis, Hacettepe University. Retrieved from https://tez.yok.gov.tr/UlusalTezMerkezi/tezSorguSonucYeni.jsp

Zoghbi, P. (2009). Inequity, conflict, and compliance dilemma as causes of cyberloafing. International Journal 
of Conflict Management, 20(2), 118-201. https://doi.org/10.1108/10444060910949630

\section{Copyrights}

Copyright for this article is retained by the author, with first publication rights granted to the journal.

This is an open-access article distributed under the terms and conditions of the Creative Commons Attribution license (http://creativecommons.org/licenses/by/4.0/). 